\title{
ROLE OF CROP ROTATION ON Rotylenchulus reniformis POPULATION WITH REFERENCE TO ITS MANAGEMENT ON COTTON PLANT, Gossypium barbadense IN CEMENT BINZES UNDER OUTDOOR CONDITIONS. \\ El-Sherif, A. G. *; A. E. M. Khalil ${ }^{\star \star}$ and A. R. Refaei* \\ * Nematology Research Unit, Agriculture Zool. Dept., Fac. Of Agric., Mansoura Univ. \\ ** Nematology Division, Plant Pathology Res. Inst., Centre, Giza, Egypt
}

\begin{abstract}
Population behavior of Rotylenchulus reniformis as artificial infestation on winter crop i.e. Egyptian clover, Triffolium alexandrinum or broadbean, Vicia faba preceding cotton cv. Giza 45 as summer crop through crop rotation system as well as its management using certain organic matters i.e. camel, horse manures, dried leaf powder of perwinkle and adhatoda in comparison with a herbicide (Emax) and a nematicide, (oxamyl) during the growing season 2005/2006 was studied within cement binzes under outdoor conditions. Results reveal that $R$. reniformis population fluctuated in soil of winter crops, increased from 200 individuals per $250 \mathrm{~g}$. soil as the initial population to 264 or 300 individuals per $250 \mathrm{~g}$. soil of Egyptian clover or broadbean in December 2005 and then declined down to 170 or 190 individuals / 250 g. soil in March, 2006 where soil temperature reached $19 \pm 5^{\circ} \mathrm{C}$, respectively, after cotton cv. Giza 454 seeds sowing. With respect to its management on cotton, oxamyl sharply suppressed nematode population below the economic threshold level that was 125 individuals per $250 \mathrm{~g}$. soil throughout the growing season. Periwinkle dried leaf powder ranked second to oxamyl in suppressing nematode count, followed by Emax and camel manure with values of $78.92 \%, 69.95 \% 68.35 \%$ and $56.87 \%$, respectively. Also, rate of nematode build-up on cotton roots under stress of the various tested treatments was adversely affected with range between 0.11 to 1.11 vs 1.04 folds for the check one. Oxamyl treatment had the lowest rate of nematode build-up (0.11), while adhatoda powder had the highest one (4.20). Meanwhile, cotton yield, percentage increase values was $41.6 \%, 33.0 \%, 25.0$ and $15.0 \%$ for oxamyl, periwinkle powder, Emax and camel manure, whereas, the lowest values were recorded by horse manure (8.3\%) and adhatoda powder (5.0\%), respectively.

Keywords: Cotton, Gossypium barbadense, reniform nematode, Rotylenchulus reniformis, seasonal fluctuation, organic manures, oxamyl, Emax
\end{abstract}

\section{INTRODUCTION}

Cotton, Gossypium barbadense constitutes one of the main agriculture national income of Arab Republic of Egypt, In certain cotton fields, plants exhibit symptoms of decline which account for a considerable loss in yield. Such phenomenon is attributed to various complex biotic and non-biotic factors. In many of the cotton growing areas of the world, several plant parasitic nematode are known to cause serious damage to cotton. The reniform nematode, Rotylenchulus reniformis, the lesion nematode, Pratylenchus brachyurus, the root-knot nematode, Meloidogyne incognita, and the sting nematode, Belonolaimus longicaudatus (Salem, 1970, Star and Page, 1990 ; El-Sherif, 1976 and Crow et. al., 1997) are examples of the 
most devastating nematode pests of cotton. The first three nematode species are widely distributed in the cultivated cotton areas of Egypt, causing remarkable crop losses. In recent survey of plant parasitic nematode associated with the rhizosphere of cotton cvs, Giza 86 and 45 grown in fourteen locations of season 2005 and 2006, twelve nematode genera i.e. Tylenchus, Tylenchorynchus, Xiphinema, Meloidogyne, Rotylenchus, Hirschamanniella, Trichodorus, Hoplaimus, Rotylenchulus, Helicotylencus, Psilenchus and Pratylenchus for Dakahlia, whereas, nine only i.e. Meloidogyne, Tylenchus, Tylenchorynchus, Heterodera, Dorylaimus, Hirschamanniella, Helicotylencus, Aphelehus and Psilenchus for Damaita, that were recorded in cotton cv. Giza fields surveyed, (El-Sherif et.al. 2007). Moreover, they also found that cotton cv. Giza 86 appeared to encounter the highest number of nematode genera (10) while, Giza 45 gained (5) only. Meanwhile, they also said that based on root gall index and $\mathrm{R}$ factor of $M$. incognita infecting cotton cultivars tested, Giza 89 was scored as resistant, while Giza 45 as well as Giza 86 were rated as susceptible hosts, since their root gall indices were 2.5 and 4 with $R$ factor values of $0.4,2.3$ and 1.11, respectively. Due to the lack information concerning the seasonal change of $R$. reniformis population in winter crops preceding summer crop such as cotton as well as its management on cotton using certain organic matters, the present investigation deals with the following points: (1) Influence of preceding winter crops on the population of $R$. reniformis infesting cotton plant cv. Giza 45 as summer crop under outdoor conditions, and (2) $R$. reniformis mangemnt on cotton plant cv. Giza 45 using certain organic matters in comparison with a herbicide or a nematicide under outdoor conditions at $27 \pm 3^{\circ} \mathrm{C}$.

\section{MATERIALS AND METHODS}

\section{A. Seasonal fluctuations of reniform nematode, Rotylenchulus reniformis population on certain winter crops followed by cotton plant through crop rotation under outdoor conditions.}

In order to study the seasonal fluctuation of $R$. reniformis population through crop rotation under outdoor conditions, Egyptian clover, Triffolium alexandrinum or broadbean, Vicia faba as winter crops were chosen in this study followed by cotton plants as summer crop during the growing season of $2005 / 2006$. To do this procedure, nine cement binzes $(60 \times 100 \mathrm{~cm})$ for each winter crop, i.e. Egyptian clover or broadbean was cultivated in steamsterilized sandy loam soil (1:1, v:v) and artificially infested with 200 immature females of $R$. reniformis before sowing . Soil samples (250 g. per each binz / crop / replicate) was separately collected in a plastic bag monthly after seed germination starting by 15th November, 2005 until 15th March, 2006. Soil samples were kept in the refrigerator at $4{ }^{\circ} \mathrm{C}$ until nematode extraction. Nematode extraction was carried-out through sieving and modified Baermann-technique (Goodey, 1957), fixed the nematode suspension with $4 \%$ formalin, then examined under the stereomicroscope, determined the number by the Hawksely counting slide and recorded. Soil temperature was 
monthly recorded during the course of the work. At the end of March 2006, cotton cv. Giza 45 seeds as summer crops were planted at the level of 15 seeds with 5 seed / location at three locations per each binz after harvesting Egyptian clover as well as broadbean and the agriculture practice for cotton cultivation was previously done according to the Egyptian procedure. Fifteen days after cotton seeds germination, cotton seedlings were thinned into one seedling / location with three cotton seedling per each binz. At the middle of April and May (15th , 2006), soil samples was separately taken from binzes of cotton seedling and the levels of nematode ( $R$. reniformis) per $250 \mathrm{~g}$. soil were recorded.

B. Management of Rotylenchulus reniformis on cotton plant cv. Giza 45 by certain organic matters in comparison with a herbicide or a nematicide under outdoor conditions at $27 \pm 3 \circ \mathrm{C}$.

In order to do such experiment, two animal wastes, i.e. camel or horse manures, two dried leaf plant powders, i.e. periwinkle, adhatoda at the rate of $5 \mathrm{~g} /$ plant with five plants / binz in comparison with a herbicide (Emax) $(0.3 \mathrm{~g} /$ plant) and Vydate (Oxamyl 24\% L.) $(0.3 \mathrm{ml} /$ plant) and three binzes were left with nematode at the level of 156 individuals (Pi) / $250 \mathrm{~g}$. soil for the preceding broadbean and 150 individuals $(\mathrm{Pi}) / 250 \mathrm{~g}$ soil for Egyptian clover on 15th May, 2006. Forty five days from adding all tested materials, soil samples from each binz / replicate / treatments were continuously taken in plastic bags until the end of the experiment, kept in the refrigerator at $4{ }^{\circ} \mathrm{C}$ until nematode extraction. Nematode extraction /treatment / replicate was proceeded as mentioned before examined and recorded. Soil temperature was also taken and recorded monthly at time of sampling. At the end of the experiment on 15th October, 2006, cotton yield was collected per replicate/ treatment and recorded.

\section{RESULTS AND DISCUSSION}

1. Seasonal fluctuations of Rotylenchulus reniformis population on winter crops followed by summer crop rotation under outdoor conditions.

Data in Tables (1\&2) illustrate the seasonal fluctuation of $R$. reniformis population on certain winter crops i.e. Egyptian clover or broad bean in monthly in $250 \mathrm{~g}$. soil cultivated in artificial infested soil of cement binzes $(60 \times 100 \mathrm{~cm})$ during the season of $2005 / 2006$. Results indicate that $R$. reniformis population fluctuated in soil of winter crops i.e. either Egyptian clover or broad bean, since its values was 128 or 200 individuals $/ 250 \mathrm{~g}$. soil in November 2005, increased up to 264 or 300 individuals $/ 250 \mathrm{~g}$. soil in December then declined down to 170 or 150 individuals $/ 250 \mathrm{~g}$. soil in January 2006 due to temperatures at this time of the year that were recorded to be $19 \pm 6^{\circ} \mathrm{C}, 17 \pm 4^{\circ} \mathrm{C}$ and then $12 \pm 5^{\circ} \mathrm{C}$, respectively. The nematode population continued to decline in soil of either winter crops under study until March with average number of 170 or 190 individuals $/ 250 \mathrm{~g}$. soil at soil temperature of $19 \pm 5^{\circ} \mathrm{C}$, even after sowing cotton seeds c. Giza 45 at the end of March, followed by April and May with average number of 150 or 100 and 
150 or 156 individuals $/ 250 \mathrm{~g}$. soil, respectively, at soil temperature ranged from $20 \pm 5^{\circ} \mathrm{C}$ to $24 \pm 3^{\circ} \mathrm{C}$.

The present findings are in agreement with those of Osman (1977) who reported that winter crops, which commonly precede tomato cultivated resulted in variable degrees of root-knot nematode infecting tomato plants.

Table (1): Cotton renifom nematode, Rotylenchulus reniformis population change in soil of winter crops of Egyptian clover and broad bean preceding cotton cv. Giza 45 as summer crop during the growing season of 2005/2006 under outdoor conditions at $18 \pm 5^{\circ} \mathrm{C}$.

\begin{tabular}{|l|c|c|c|}
\hline \multirow{2}{*}{ Months } & \multicolumn{3}{|c|}{${ }^{*}$ Average number of Rotylenchulus reniformis on } \\
& $(\mathbf{A})$ : winter crops \\
\cline { 2 - 4 } & Broadbean & Egyptian clover & Temperature \\
\hline November 2005 & 200 & 128 & $19 \pm 6$ \\
\hline December & 264 & 300 & $17 \pm 4$ \\
\hline January 2006 & 170 & 150 & $12 \pm 5$ \\
\hline February & 130 & 110 & $14 \pm 5$ \\
\hline March & 170 & 190 & $19 \pm 5$ \\
\hline \multicolumn{4}{|c|}{ (B); Summer crop, cotton cv. Giza 45 } \\
\hline April & 150 & 100 & $20 \pm 5$ \\
\hline May & 150 & 156 & $24 \pm 3$ \\
\hline
\end{tabular}

Initial population = 200 immature females of $R$. reniformis $(\mathrm{Pi})$

${ }^{\star}$ Each figure $=$ mean of three replicates.

Table (2): Fluctuation of $\boldsymbol{R}$. reniformis number, rate of reproduction and reduction during cotton growing season 2006 following winter crops as affected by certain organic amendments under outdoor conditions at $27 \pm 3$ 으.

\begin{tabular}{|l|c|c|c|c|c|c|c|c|}
\hline \multirow{2}{*}{ Months } & \multicolumn{7}{|c|}{${ }^{*}$ Average number of $\begin{array}{r}R \text { reniformis per 250g. soil during cotton } \\
\text { growing season 2006 }\end{array}$} \\
\cline { 2 - 10 } & June & July & August & September & $\begin{array}{c}\text { October } \\
\text { (PF) }\end{array}$ & $\begin{array}{c}\text { Cumulative } \\
\text { Number }\end{array}$ & $\begin{array}{c}\text { No. } \\
\text { Of } \\
\text { folds }\end{array}$ & $\begin{array}{c}\% \\
\text { Red. }\end{array}$ \\
\hline $\begin{array}{l}\text { Treatments } \\
\text { manure }\end{array}$ & 120 & 129 & 120 & 125 & 44 & 538 & 0.28 & 56.89 \\
\hline $\begin{array}{l}\text { Horse } \\
\text { manure }\end{array}$ & 114 & 160 & 112 & 120 & 117 & 623 & 0.76 & 50.08 \\
\hline $\begin{array}{l}\text { Periwinkle } \\
\text { powder }\end{array}$ & 110 & 80 & 60 & 65 & 60 & 375 & 0.39 & 69.95 \\
\hline $\begin{array}{l}\text { Adhatoda } \\
\text { powder }\end{array}$ & 111 & 120 & 110 & 132 & 170 & 643 & 1.11 & 48.48 \\
\hline Emax & 120 & 105 & 50 & 60 & 60 & 395 & 0.38 & 68.35 \\
\hline $\begin{array}{l}\text { Oxamyl } \\
\text { N alone }\end{array}$ & 29 & 60 & 50 & 55 & 18 & 263 & 0.11 & 78.92 \\
\hline
\end{tabular}

Initial population = 153 individuals $/ 250 \mathrm{~g}$. soil.

Rate of reproduction $(\mathbf{P f})=$ (Final population /(Pf / intial population) $(\mathbf{P i})$.

${ }^{\star}$ Each figure $=$ mean of three replicates 
2. Management of Rotylenchulus reniformis on cotton plant cv. Giza 45 by certain organic matters in comparison with a herbicide or a nematicide under outdoor conditions at $27 \pm 3$ ㅇ․

Data in Tables (2\&3) Figure (1) show the effect of certain organic matters i.e. camel, horse manures, dried leaf plant powders of periwinkle and adhatoda in comparison with a herbicide (Emax) and Oxamyl on controlling $R$. reniformis and cotton growth yield during cotton growing season of 2006, following the winter crops i.e. Egyptian clover or broad bean of 2005 under outdoor conditions at $27 \pm 3^{\circ} \mathrm{C}$. Data reveal that treatment with oxamyl or a herbicide (Emax) or periwinkle dried leaf plant powder, obviously, reduced and maintained the population of $R$. reniformis at the lowest level through the growing season of cotton. On the other hand, adhatoda treatment dropped the population till August then reached its maximum almost as the check (untreated) during October, where, camel or horse manures treatments dropped nematode population in June $(-5$ or -11$)$, increased up to $(+4$ or +35 ), in July and then, sharply declined again in August, September and October, respectively. (Table 3).

Table (3): Rate of cotton raw yield increase as affected by Rotylenchulus reniformis infection under the stress of certain organic amendments treatments in comparison with a herbicide and oxamyl during growing season 2006 under outdoor conditions at $27 \pm 3^{\circ} \mathrm{C}$.

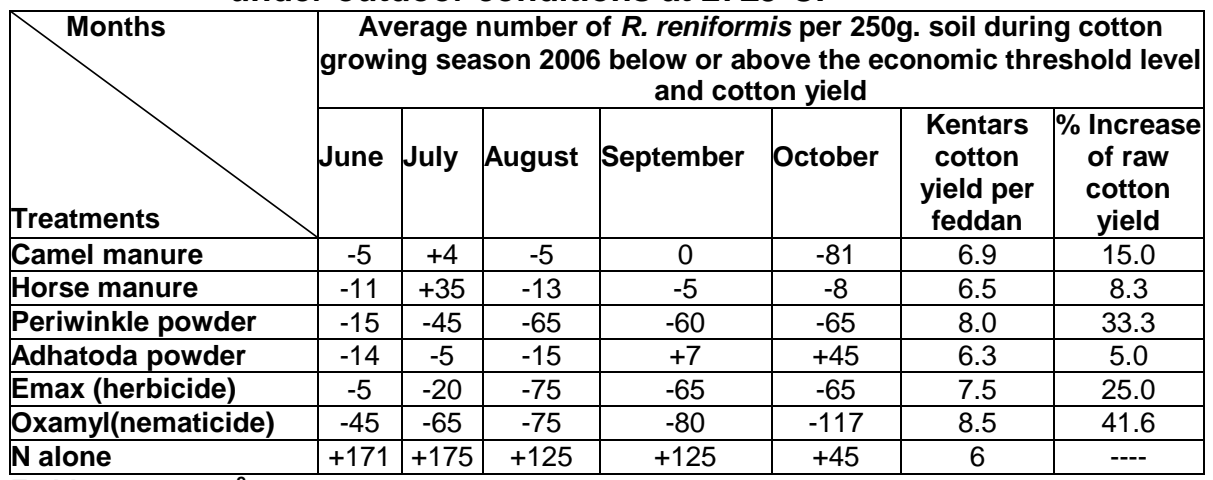

Feddan $=4200 \mathrm{~m}^{2}$

Kentar raw cotton $=150 \mathrm{Kg}$.

Hectar $=10.00 \mathrm{~m}^{2}$

Generally the population level sharply suppressed after harvesting to a level below the initial density in most treatment (Fig. 1) Obviously, the economic threshold level of $R$. reniformis population was about 125 individuals $/ 250 \mathrm{~g}$. soil throughout the cotton growing season (Fig. 1). Data also reveal that oxamyl sharply suppressed nematode population below the economic threshold level, followed by the herbicide (Emax) and dried leaf plant powder of periwinkle treatments during June, July August, September and October. With adhatoda treatment the same result was obtained except in September and October at which time nematode population was 7 and 45 individuals above the threshold level (Table, 3). Among the tested organic 
El-Sherif, A. G. et al.

matters, Periwinkle dried leaf powder ranked first in suppressing the cumulative number of $R$. reniformis, followed by camel manure with value of $69.95 \%$ and $56.89 \%$, respectively. As a whole oxamyl treatment gave the highest reduction percentage in suppressing nematode population with value of $78.92 \%$ followed by periwinkle dried leaf powder $(69.95 \%)$, then the herbicide (Emax) (68.35\%), and camel manure (56.89\%), respectively.
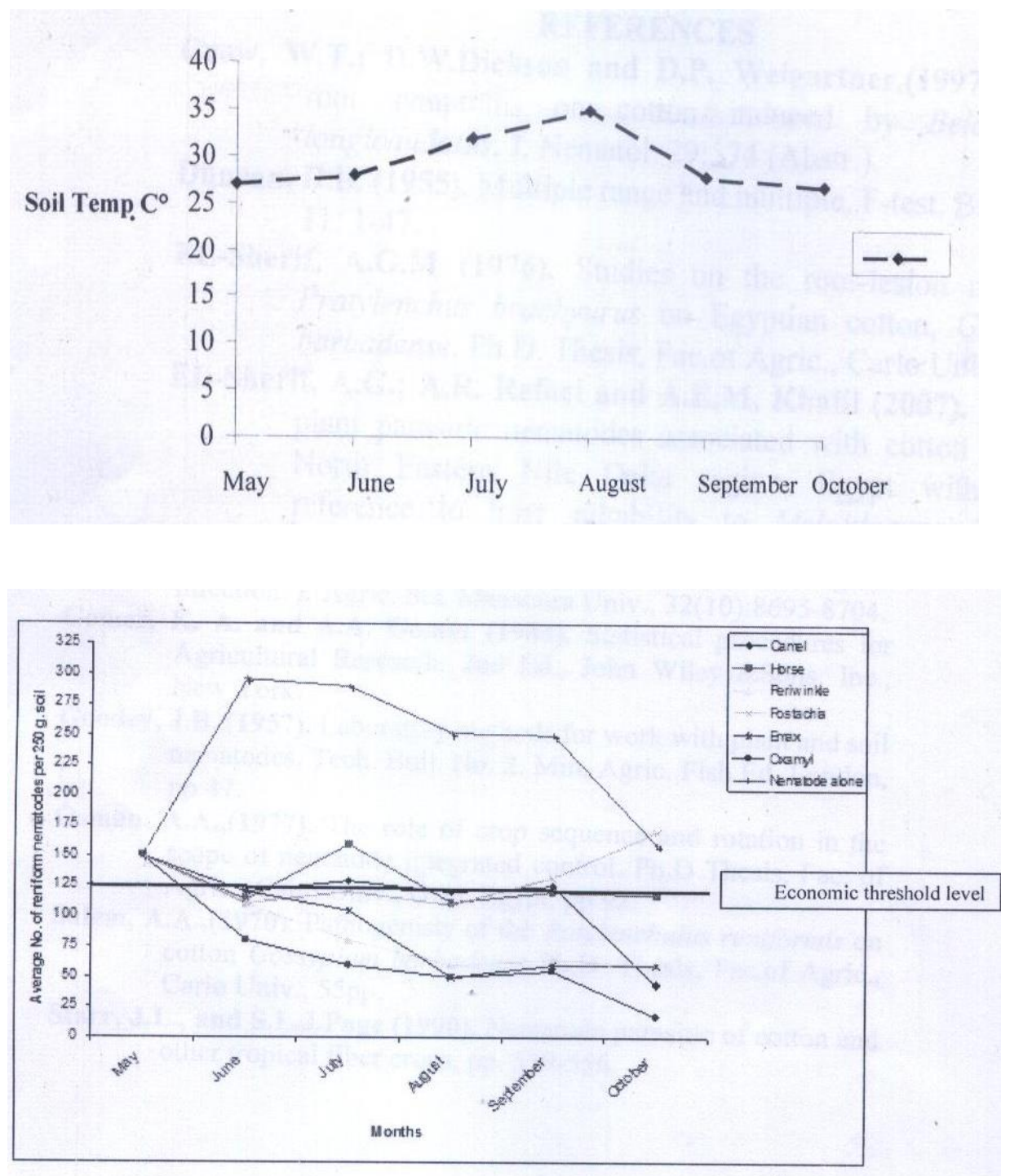

Fig. (1): Average number of Rotylenchulus reniformis on cotton plant as affected by the addition of certain treatments. 
Also, rate of nematode build-up on cotton roots under stress of the various tested treatments was adversely affected. Such rates ranged from 0.11 to 1.11 vs 1.04 folds for the check one. Oxamyl treatment had the lowest rate of nematode build-up with value of 0.11 , while, adhatoda powder had the highest rate one (1.11). It is worthy to note that all tested treatments kept $R$. reniformis in low number below the economic threshold level which was recorded to be 125 individuals / $250 \mathrm{~g}$. soil during cotton growing season 2006 except that of adhatoda at the end of cotton season (Fig. 1). Meanwhile, oxamyl gave the highest percentage increase of cotton yield (41.6\%), followed by periwinkle dried leaf powder $(33.0 \%)$, then herbicide treatment $(25.0 \%)$, and camel manure $(15.0 \%)$, whereas, adhatoda dried leaf powder had the lowest percentage increase of cotton yield (5.0\%) and horse manure (8.3\%) comparing to nematode alone, respectively.

The present findings are in agreement with those of Osman (1977) who said that the effect of Vydate (oxamyl) spray on tomato infected with $M$. javanica indicated that this compound resulted in more than $90 \%$ nematode reduction and significantly increased the plant growth. Also, results of the present work are supported by those of El-Sherif (1976) who reported that aldicarb as a nematicide in particular, controlled $P$. brachyurus and obviously increased cotton yield. The economic threshold level was determined as 100 nematode $250 \mathrm{~g}$. soil throughout cotton growing season )El-Sherif, 1976).

\section{REFERENCES}

Crow, W. T.; D. W. Dickson and D. P. Weigartner, (1997). Stubby root symptoms on cotton induced by Belonolaimus logicaudatus. J. Nematol. 29:574 (Abstr).

Duncan, D.B. (1955). Multiple range and multiple, F-test. Biometrics, 11: 142.

El-Sherif, A. G. M. (1976). Studies on the root-lesion nematode, Pratylenchulus brachyurus on Egyptian cotton, Gossypium barbadense. Ph. D. Thesis, Fac. of Agric., Cario Univ., 94pp.

El-Sherif, A. G. ; A. R. Refaei and A. E. M. Khalil (2007). Status of plant parasitic nematodes associated with cotton fields in North Eastern Nile Delta Region, Egypt with special reference to host suitability to Meloidogyne incognita infection. J. Agric. Sci.Mansours Univ., 32 (10): 8695-8704.

Gomez, K. A. and A.A. Gomez (1984). Statistical procedures for Agricultural Research. 2nd Ed., John Wiley \&Sons: Inc., New York.

Goodey, J.B. (1957). Laboratory methods for work with plant and soil nematodes. Tech. Bull. No. 2. Min. Agric. Fish Ed. London, 47 pp.

Osman, A. A. (1977). The role of crop sequence and rotation in the scop of nematode integrated control. Ph. D. Thesis, Fac. of Agric., Cario Univ. Giza, Egypt, 92pp.

Salem, A. A., (1970). Pathoginicity of the Rotylenchulus reniformis on cotton Gossypium barbadense Ph. D. Thesis , Fac. of Agric., Cario Univ., 55pp. 
El-Sherif, A. G. et al.

Starr, J. L. and S. L. J. Page (1990). Nematode parasitic of cotton and other tropical fiber crops, 539-556pp.

دور دورة المحاصيل علي تعداد نيماتودا "روتيلنكيولس رينفورمس " بالاشسارة السي

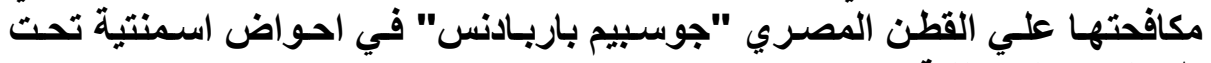

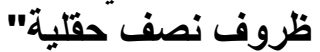

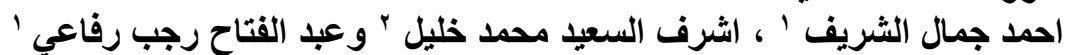

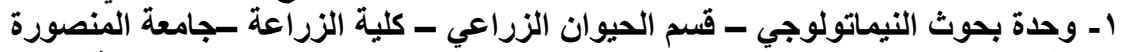

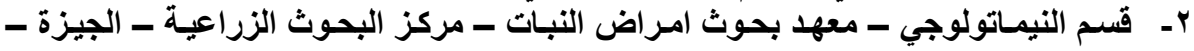
مصر.

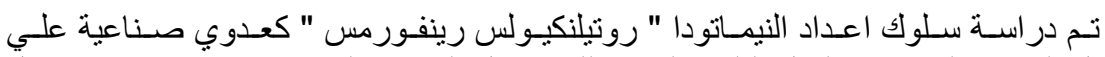

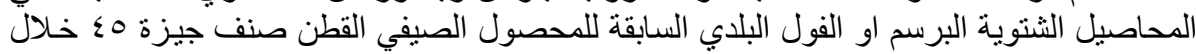

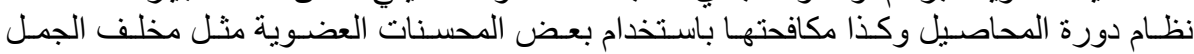

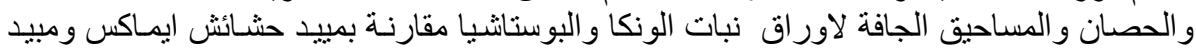

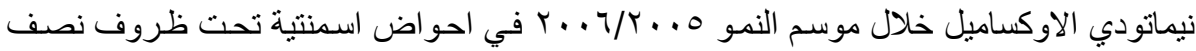
حقلية

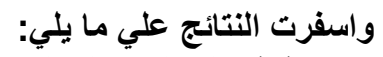

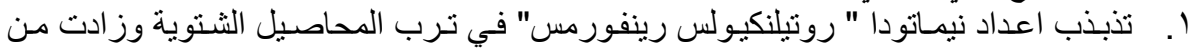

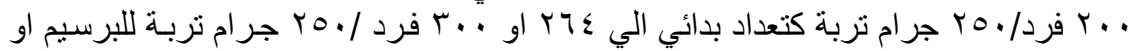

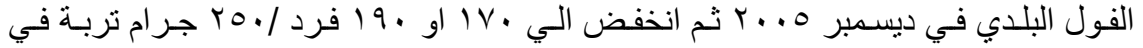

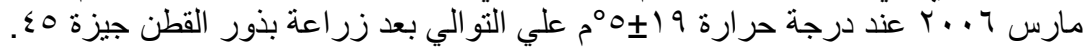

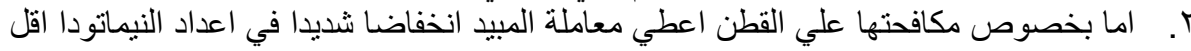

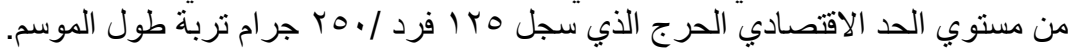

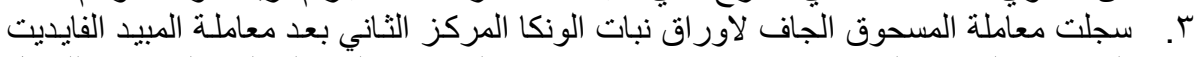

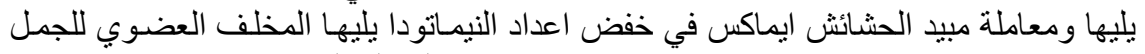

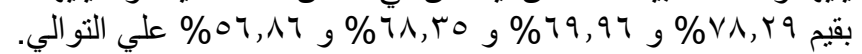

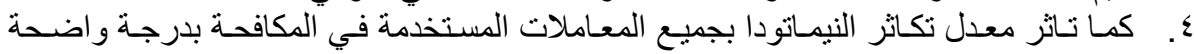

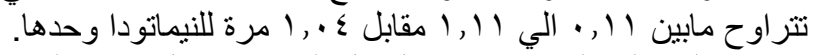

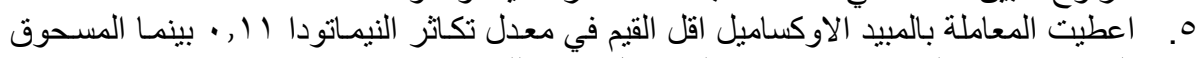

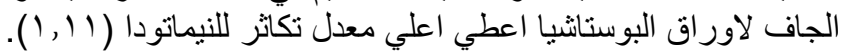

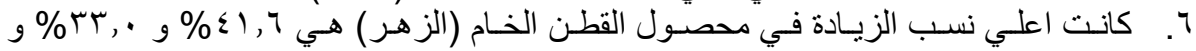

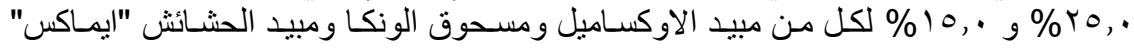

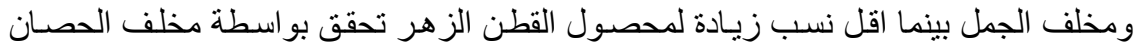

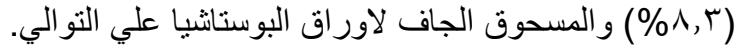

